\title{
Migration, gene flow and reproductive isolation between and within morphotypes of the isopod Excirolana in two oceans
}

\author{
H. A. LESSIOS \& JAMES R. WEINBERG* \\ Smithsonian Tropical Research Institute, Box 2072, Balboa, Panama and *National Marine Fisheries Service, Population \\ Dynamics Branch, 166 Water Street, Woods Hole, MA 02543, USA
}

The rate of gene flow between populations depends both on the dispersal ability of the organism and on the probability that migrants can successfully mate with residents. The degree to which this reproductive isolation can impede genetic exchange can be assessed by studying both migration and gene flow. We carried out such a study in Panamanian populations of Excirolana, an intertidal isopod with no planktonic larvae that inhabits both coasts of Central and South America. In Panama Excirolana is represented by three morphs of E. braziliensis (two closely related and found on opposite sides of Central America, a third only in the eastern Pacific) and by E. chamensis. Because populations of Excirolana from each beach in Panama, regardless of species or morphotype affiliation, are characterized by a unique combination of alleles, this isopod provides the opportunity to use genetic data to determine the number of immigrants that land on a given beach as well as the number of individuals that transfer alleles between populations. We studied isozyme patterns of 10 populations of $E$. braziliensis and one population of $E$. chamensis. Rates of gene flow were estimated both from $F_{\mathrm{ST}}$ statistics and from private alleles. In contrast to the private allele method, $F_{\text {ST }}$ statistics gave results that were internally consistent in that they produced lower estimates of apparent gene flow between oceans and recognized species than they did between populations of the same morph. Rate of gene flow between populations belonging to the two morphs of $E$. braziliensis in the eastern Pacific was as low as apparent gene flow across the Central American isthmus and no larger than the rate of genetic exchange between E. braziliensis and E. chamensis. One locality that contained both morphs in sufficiently large numbers showed heterozygote deficits relative to Hardy-Weinberg expectations. Reproductive isolation is, therefore, of sufficient strength to justify the conclusion that the two Pacific morphs of E. braziliensis should be assigned to different species. Gene flow rate between populations of the same morph was an order of magnitude larger than rate of gene exchange between morphs but still less than one propagule per generation. Rate of immigration into every beach, calculated from the number of homozygotes of rare alleles (in excess of what would be expected from random matings among the residents), was surprisingly high for an organism with apparently limited means of dispersal and with fixed genetic differences between adjacent populations. Individuals of $E$. braziliensis evidently move between beaches much more freely than alleles move between populations. Therefore, some degree of reproductive isolation exists even between genotypes that belong to the same morph.

Keywords: diagnostic loci, dispersal, $F_{\mathrm{ST}}$ statistics, geographic variation, isozymes, private alleles.

\section{Introduction}

The rate of gene flow between populations depends both on the dispersal ability of the organism relative to geographic obstacles to migration and on the probability that successful migrants can mate with residents and leave behind viable offspring. Although in popula- tion genetics the terms 'migration' and 'gene flow' are often used interchangeably (thus implying that migrants can cross at random with residents), assortative mating or lower fitness of hybrids can result in low rates of gene flow despite high migration (Endler, 1977). These biological barriers to genetic exchange are collectively referred to as reproductive isolation and have been 
studied intensively with regards to speciation. However, they can also be present in varying degrees between populations of the same nominal species either because such a taxonomic entity encompasses more than one biological species, or because they may constrict gene flow but not interrupt it completely. Simultaneous estimates of migration and gene flow can determine the degree of reproductive isolation between populations thought to belong to the same species. In doing so, they can uncover previously unsuspected events of speciation or they can assess the degree to which reproductive isolation impedes gene flow between populations that still belong to the same species.

Species in which different populations are characterized by distinct genetic traits provide the opportunity to use natural markers to study rates of migration and compare them with rates of gene flow. Of course, such species form a preselected group because the existence of unique traits in each population will usually come from low levels of gene flow. However, they permit an assessment of the degree to which limited gene flow is the result of geographical obstacles that prevent migration or of biological barriers that restrict genetic exchange between migrants and residents.

Excirolana braziliensis is a dioecious marine isopod that lives in the high intertidal zone of sandy beaches on both sides of tropical and subtropical America. It possesses no larval stage. The female broods 4-17 embryos, then releases them into the parental habitat (Dexter, 1977). Adults remain buried in the sand during periods of low tide. At high tide individuals of Excirolana emerge into the water column, where they may attach to prey, such as live or dead fish, usually for a few seconds (J. R. Weinberg, personal observation) or minutes (Brusca, 1980). Any dispersal from beach to beach probably takes place by rafting or by freeswimming. There are no reliable data on the generation time of E. braziliensis, but Brusca \& Iverson (1985) estimate the period of population turnover to be about 4 months.

Studies of the multivariate morphometrics of $E$. braziliensis have revealed the existence of three morphs, two of them closely related and found on opposite sides of Central America, the third found predominantly in the eastern Pacific but also on the coast of southern Brazil (Weinberg \& Starczak, 1988, 1989).

Weinberg \& Starczak (1989) have labelled the Caribbean morph as ' $C$ ', its close counterpart in the eastern Pacific as ' $\mathrm{C}$ ', and the eastern Pacific morph as ' $\mathrm{P}$ '. Collections from 43 beaches from the entire range of E. braziliensis demonstrated that with only two exceptions each beach contains an overwhelming majority of one morph at any given time. Although the reasons for this pattern of exclusive occupation of each beach by a single morph are unclear, intensive sampling of three beaches (Weinberg \& Starczak, 1988) revealed that it is not a sampling artefact. Weinberg \& Starczak $(1988,1989)$ attributed the presence of a few morphological outliers in some localities to limited immigration from other beaches. Although they rarely co-occur on the same beach, on a broader geographic scale the $\mathrm{P}$ and $\mathrm{C}^{\prime}$ morphs are sympatric in the sense that their ranges coincide in a broad mosaic of no discernible geographical pattern. Bott (1954) and Schuster (1954) have each described a new species of Excirolana from the eastern Pacific, but Glynn et al. (1975) and Brusca \& Iverson (1985) concluded that these were simple morphological variants and that populations throughout the extended ranges in both oceans belong to E. braziliensis. More recently, Brusca \& Weinberg (1987) described a new species, Excirolana chamensis, from the Pacific coast of Panama.

A study of multivariate morphology and isozymes of 10 Panamanian populations of Excirolana braziliensis and one population of E. chamensis (Lessios \& Weinberg, in press) has found that morphological and genetic divergence between populations are highly correlated, that the $\mathrm{P}$ morph is as divergent from the other morphotypes of E. braziliensis as E. braziliensis is from $E$. chamensis and that every population, regardless of morphology, can be differentiated from every other on the basis of loci that differ diagnostically. Because of the magnitude of divergence and the probable phylogenetic relations between morphs, Lessios \& Weinberg (in press) concluded that the $\mathrm{P}$ and $\mathrm{C}^{\prime}$ morphs probably constitute different species.

A four-year study of morphological and genetic stability of Excirolana braziliensis and E. chamensis (Lessios et al., in press) revealed that populations in nine localities remained unchanged, whereas both isozymes and morphology in a tenth locality changed so drastically within 2 years that replacement of one population by another was the most likely explanation. Such extinction and recolonization events constitute a form of gene flow when they are frequent and when the colonists are derived from several populations (Maruyama \& Kimura, 1980; Slatkin, 1985a; Ewens et al., 1987; Barton, 1988); however, when these events occur infrequently, and when the propagules are drawn from a single population, they can exert a strong differentiating effect due to genetic drift (Wright, 1940; Selander, 1975; Slatkin, 1977; Wade \& McCauley, 1988; Whitlock \& McCauley, 1990; McCauley, 1991). As Excirolana braziliensis appeared to meet all the criteria of a species in which local populations could 
diverge due to extinction and recolonization, Lessios $e t$ al. (in press) and Lessios \& Weinberg (in press) concluded that these processes could account for the high degree of local differentiation between its populations. The genetic data used by Lessios \& Weinberg (in press) to assess divergence in E. braziliensis and E. chamensis are used here to estimate gene flow. The finding of Lessios and Weinberg that there is at least one locus that diagnostically distinguishes between any two of the 11 studied populations provides the basis of estimating rates of migration to be contrasted with rates of gene flow. The two analyses are combined to address the following questions. (1) How much gene flow is there between populations that belong to the same morph and populations that belong to separate morphs? (2) How reliable are estimates of gene flow and how do they compare with estimates of migration? (3) Are constrictions of gene flow between morphs and between populations that belong to the same morph due to low dispersal or do they come from reproductive isolation?

The analysis of patterns of gene flow is greatly aided by the sampling of localities in two oceans. Atlantic and Pacific populations were separated 3 to 3.5 million years ago by the rise of the isthmus of Panama (Saito, 1976; Keigwin, 1978, 1982; Coates et al., 1992). They provide a fixed historical point at which gene flow was severed, information that can put in perspective the calculated estimates of gene flow rates between populations in the same ocean.

\section{Materials and methods}

Excirolana was sampled at 11 localities on the two coasts of Panama (Fig. 1). Three localities on the
Atlantic coast contained the C morph of Excirolana braziliensis. With the exception of one individual in each of two beaches, four localities on the Pacific side were inhabited exclusively by the $\mathrm{P}$ morph and two exclusively by the $C^{\prime}$ morph of this species; Santelmo contained a mixture of $\mathrm{P}$ and $\mathrm{C}^{\prime}$. The sample from Punta Chame consisted of E. chamensis. With the exception of two beaches (Perico and Santelmo), duplicate samples were obtained, one between 4 and 26 February 1986 and one between 17 September and 31 October, 1988. Methods of electrophoresis are described in Lessios \& Weinberg (in press). Briefly, 17 loci, coding for 14 enzymes were scored. These were: alkaline phosphatase (Alkph-1 and Alkph-2), esterases (Est-1 and Est-2), $N$-acetyl- $\beta$-glucosaminidase $(\beta G a)$, fructokinase $(F k)$, fumarate dehydrogenase $(F u m)$, glutamate-oxaloacetate transaminase $(G o t)$, glutamic dehydrogenase (Glutdh), $\alpha$-glycerophosphate dehydrogenase ( $\alpha$ Glyphdh), mannose-6-phosphate isomerase (M6pi), $\mathrm{NAD}^{+}$dependent malate dehydrogenase $(M d h-1$ and $M d h-2)$, L-leucyl-L-tyrosine peptidase (Peplt), phosphoglucose isomerase (Pgi), phosphoglucomutase $(P g m)$ and triosephosphate isomerase $(T p i)$.

Technical problems prevented the collection of data for some loci from one of the samples of some populations; the statistics reported in this paper were calculated on the basis of the loci that were sampled in all populations during a particular time period, i.e. 12 loci in 1986 and 16 loci in 1988 (Appendix). Null alleles had to be postulated in Alkph-2 at Isla Adentro, Isla Culebra and Punta Chame and in Est-1 at Shimmey Beach and Isla Porcada. The majority of individuals from these populations showed no activity
Fig. 1 Locations at which isopods were sampled. Morphotype of Excirolana braziliensis at each beach is given in parentheses. (1) Bocas del Toro (C). (2) Shimmey Beach (C). (3) Maria Chiquita (C). (4) Isla Porcada $(P) .(5)$ Isla Adentro $\left(C^{\prime}\right) .(6)$ Causeway Beach (P). (7) Lab Beach (P). (8) Perico (P). (9) Isla Culebra $\left(C^{\prime}\right) .(10)$ Punta Chame $(E$. chamensis). (11) Santelmo ( $C^{\prime}$ and P). Bar in insert represents $2 \mathrm{~km}$.

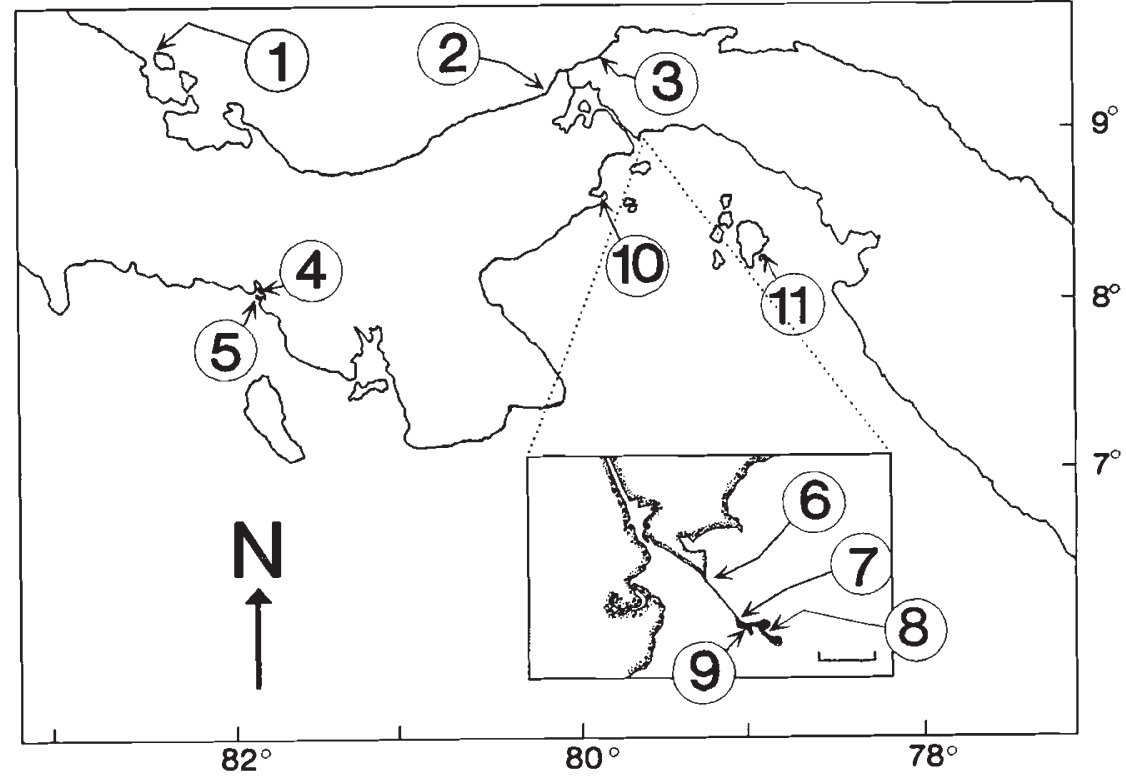


in the region of the respective locus (as determined from results from other populations) even though they possessed high activity in Alkph-l or Est-2. Because heterozygotes of null alleles cannot be recognized, Est-1 and Alkph-2 were ignored in comparisons of genotype frequencies to those expected from Hardy-Weinberg equilibrium. An additional technical difficulty was that the small size of the animals resulted in limited sample volume that prevented the determination of composite genotypes across all loci for each individual and thus an examination of possible linkage between loci. The small volume of sample also prevented the reassaying of individuals with suspected different genotypes side-by-side. Because of this limitation, the approach taken in scoring was the most conservative one possible, i.e. every doubtful case was scored so as to decrease apparent variability.

We used two methods of estimating the gene flow parameter, $\mathrm{Nm}$, i.e. the product of effective population size times the gene flow rate. One estimate comes from $F_{\text {ST }}$ statistics (Wright, 1965), the other from 'private alleles', i.e. alleles that are found in only one population (Slatkin, 1985b). The estimate from $F_{\mathrm{ST}}$ was calculated as:

$N m_{F_{\mathrm{ST}}}=\frac{\frac{1}{\bar{F}_{\mathrm{ST}}}-1}{4}$

$F_{\text {ST }}$ values were calculated using the BIOSYS computer package (Swofford \& Selander, 1989) and averaged over all polymorphic loci to produce $\bar{F}_{\mathrm{ST}}$ (Baker \& Moeed, 1987; Baker et al., 1990). The estimate from private alleles was calculated as:

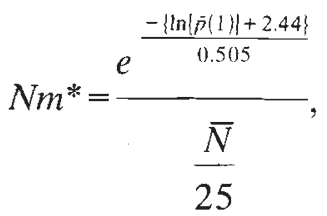

where $\bar{p}(1)$ is the average frequency of all private alleles and $\bar{N}$ is the average number of individuals sampled per locus per population (Slatkin, 1985b). $F_{\text {ST }}$ statistics and the private allele method do not always produce congruent estimates (e.g. Larson et al., 1984; Caccone \& Sbordoni, 1987; Waples, 1987; Johnson et al., 1988; Crouau-Roy, 1989).

Because each population was characterized by at least one locus that differed diagnostically from all other populations, our genetic data could also provide an estimate of the rate of migration. We reasoned that homozygotes of rare alleles at a diagnostic locus were likely to be recent arrivals from another, genetically distinct, population. We, therefore, used their proportion in each sample as an indication of how much immigration the population had received from others during the existing generation. This proportion, however, needed to be adjusted for the number of homozygotes that might exist in the population as a result of random mating of the residents. We approximated the proportion of recent immigrants, $m_{\mathrm{im}}$, by assuming that gene frequencies remained constant over time, so that we could estimate the expected number of homozygotes from the Hardy-Weinberg rule:

$$
m_{\mathrm{im}}=\frac{\sum_{j=1}^{L}\left(N_{\mathrm{komo}_{(j)}}-N_{\left.\exp _{(j)}\right)},\right.}{\sum_{j=1}^{L} N_{\mathrm{ind}_{(j)}}},
$$

where $N_{\text {homo }}$ is the number of observed homozygotes of rare alleles (all alleles except most common one) in each diagnostic locus $j$ (every locus sampled except $F k$, Fum, Mdh-2 and Peplt), $N_{\exp }$ is the number of expected homozygotes (rounded to the nearest integer) assuming Hardy-Weinberg equilibrium and using Levene's (1949) correction for small sample size, $N_{\text {ind }}$ is the number of individuals sampled for the locus and $L$ is the number of diagnostic loci.

Because different populations were distinct in different loci and because each individual was sampled for only a few loci, we could identify no individuals in our sample that were homozygous for rare alleles in more than one locus. This prevented linkage disequilibrium analysis (which would have been very useful in identifying the source population of possible migrants) but had the virtue of allowing the loci to be treated in an additive fashion in calculating rates of immigration without undue inflation of the estimate. Because we needed a measure of overall immigration in a group of populations to compare with estimates of gene flow derived from $\bar{F}_{\mathrm{ST}}$ and private allele analysis, we averaged $m_{i m}$ over all populations of each group.

Our analysis of migration is dependent on the assumption that the arrival of individuals with genotypes different than those of the resident population causes homozygote excesses relative to what would be expected from Hardy-Weinberg equilibrium. We tested conformity to Hardy-Weinberg expectations with goodness of fit chi-squared tests. Because the preponderance of one allele in each locus in every population resulted in small expected genotype frequencies for the rare alleles, significance of the departures was assessed in tests for overall heterozygosity, with homozygotes 
pooled in one class and heterozygotes pooled in another (Pamilo \& Varvio-Aho, 1984; Lessios, 1992) employing a correction for continuity of 0.25 (Emigh, 1980). Significance values were adjusted with the sequential Bonferroni procedure (Rice, 1989) to take into consideration that 74 tests were performed.

\section{Results}

Table 1 presents estimates of the gene flow rate $\mathrm{Nm}$ calculated from $F_{\text {ST }}$ statistics and private alleles. To have a standard of comparison, suggesting what $\mathrm{Nm}$ values to expect when gene flow is absent, we have followed Caccone (1985) in including estimates of gene flow between populations known or suspected not to be exchanging genes, such as Excirolana braziliensis populations from different oceans and populations of both recognized species of Excirolana. We have also calculated $N m$ for both morphs of $E$. braziliensis inhabiting the Pacific together (i.e. the $\mathrm{P}$ and the $\mathrm{C}^{\prime}$ morph) and for each morph separately. Even though Santelmo contains a substantial number of individuals that belong to the $\mathrm{P}$ morph, in this analysis we have treated it as if it belonged entirely to the $\mathrm{C}^{\prime}$ morph because this population morphologically and genetically clusters much closer to the $\mathrm{C}^{\prime}$ than to the $\mathrm{P}$ morph (Lessios \& Weinberg, in press).

How reliable are the two estimates of gene flow? Indirect estimates of gene flow are based on the assumption that populations are at genetic equilibrium (Slatkin, 1985a) or at least quasi-equilibrium (Barton \&
Slatkin, 1986). This assumption seems reasonable for all populations of Excirolana, except for those occupying Isla Porcada, because gene frequencies did not change significantly between 1986 and 1988 (Lessios et al., in press). Thus, one indication of the reliability of gene flow estimates is their apparent constancy through time. $F_{\mathrm{ST}}$ statistics yielded similar $\mathrm{Nm}$ values in the two sampling years for all morphs except $C^{\prime}$ (Table 1). The absence in the 1986 data of a sample from Santelmo and of Est-1, in which the two $\mathrm{C}^{\prime}$ populations turned out to be fixed for alternate alleles in 1988 (Appendix), were responsible for the low $F_{\mathrm{ST}}$ value and high estimated gene flow within the $C^{\prime}$ morph in 1986 relative to those in 1988 . The inadequacy of the 1986 data was also responsible for the sharp disagreement between the estimates obtained from $F_{\mathrm{ST}}$ and from private alleles from this year. $\beta G a$, Est-1, Est-2, and Tpi are loci that in 1988 contained private alleles in high frequencies (Appendix); these loci were not sampled in 1986. The number of private alleles in the 1986 data (Table 1) was too low to produce reliable estimates of gene flow (Waples, 1987). Thus, there is reason to be suspicious of the gene flow estimates obtained from 1986 data from either method but particularly of those obtained from private alleles. However, the $F_{\mathrm{ST}}$ and private allele methods produced estimates by and large congruent with each other when applied to the 1988 data. The only cases in which the two methods of estimation yielded values that differed by an order of magnitude are the ones pertaining to within-morph rates of gene flow. Because of the small

Table $1 \bar{F}_{\mathrm{ST}}$ values and gene flow and immigration parameters calculated as explained in the text

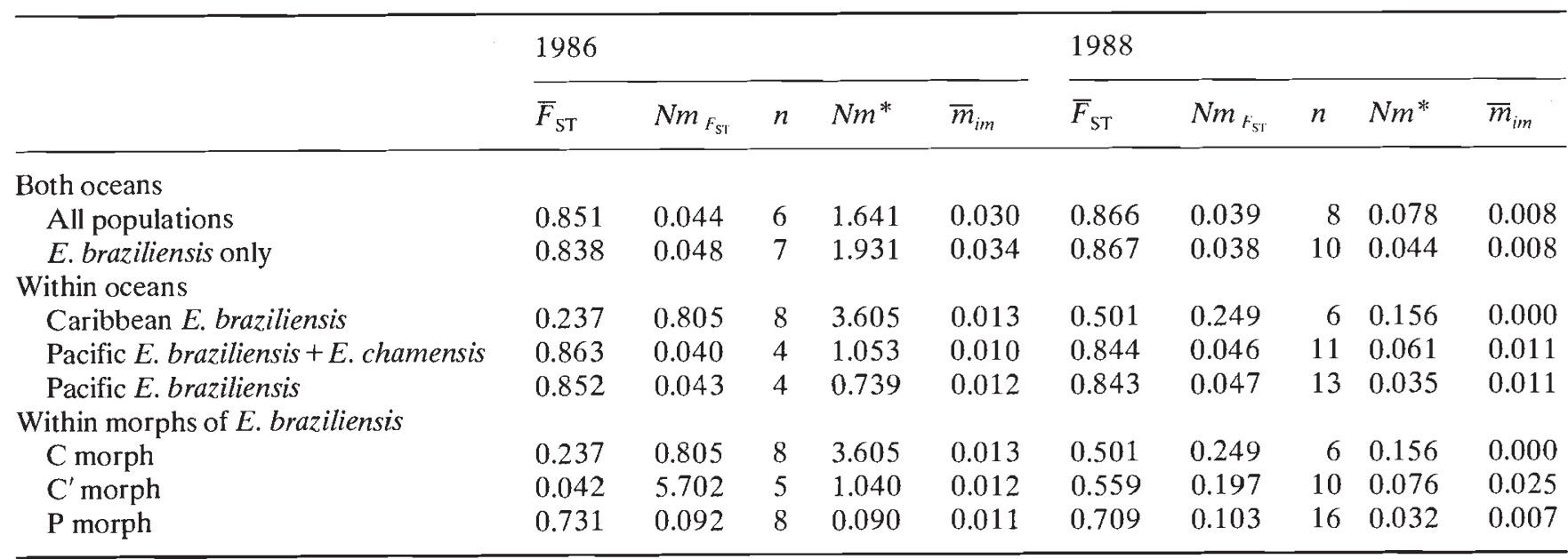

$N m_{F_{\mathrm{ST}}}$ : gene flow expressed as number of gene-transferring migrants per generation estimated from $F_{\mathrm{ST}}$ statistics. $n$ : number of private alleles. $\mathrm{Nm}^{*}$ : gene flow expressed as number of gene-transferring migrants per generation estimated from private alleles. $\bar{m}_{\text {im }}$ average immigration rate expressed as the proportion of individuals that are immigrants and calculated from homozygotes of rare alleles present in populations in excess of what is expected from Hardy-Weinberg equilibrium. Parameters were estimated from loci sampled in all populations during each of the two sampling years (12 loci in 1986, 16 loci in 1988). The Santelmo population is included with the $C^{\prime}$ morph in 1988; it was not sampled in 1986 . 
number of populations involved when gene flow calculations are limited to only one morph, both $F_{\mathrm{ST}}$ and private allele estimates are probably biased (Nei et al., 1977; Slatkin, 1985b), but in 1988 they agree in estimating $\mathrm{Nm}$ values less than unity.

An additional means of evaluating the two methods of estimation of $\mathrm{Nm}$ comes from the inclusion of populations from two oceans and two known species. As one goes from estimates of apparent gene flow between oceans or between different species to populations of a single morph in one ocean, $\mathrm{Nm}$ should remain constant or increase. Such an increase was seen in values obtained from $F_{\mathrm{ST}}$ statistics in both years but not from private alleles, even in 1988 (Table 1). If the rates of gene flow calculated from the private allele method were taken literally, we would have had to conclude that populations in the same ocean that belong to the same morph exchange fewer alleles than populations separated by the central American isthmus. Slatkin \& Barton (1989) have pointed out that the private allele method may fail in electrophoretic studies owing to the practical difficulty in distinguishing rare alleles unique to a population. This problem may apply to our study because of our conservative method of scoring differences between populations, but there is no reason to suppose that we have been more conservative in scoring gels with individuals from different oceans than in scoring gels with individuals from the same morph. Another problem of this method when applied to our data is that the relationship between the logarithm of the rate of gene flow and the logarithm of the average frequency of private alleles is not linear when $\mathrm{Nm}$ is less than 0.1 (Slatkin, 1985b). However, the chief limitation of the private allele technique when used to calculate gene flow rates in more than one morph of Excirolana came from a peculiar property of its population genetics: alleles that were private to one population when a morph was considered separately, appeared in a different morph in a different ocean, and were thus no longer private in a larger scale. Thus, the number of private alleles in 1988 when all populations were considered together was lower than the number of private alleles in two out of the three morphs when they were considered separately (Table 1). We believe that this pattern of variation was not entirely the result of conservative scoring but came from the mode of evolution of this isopod (Lessios \& Weinberg, in press).

For the reasons outlined above, we believe that the most reliable estimates of gene flow rates come from $F_{\text {ST }}$ statistics applied to the 1988 data, whereas estimates from the private allele method and from the 1986 data are only correct to the extent that they corroborate the former. The $1988 F_{\mathrm{ST}}$ estimates indicate that gene flow rates between these isopod populations were very low. Every $N m_{F_{\mathrm{ST}}}$ from the 1988 data was less than unity and this was also true for the 1986 data, except for the C morph. Thus, even local populations belonging to the same morph exchange, on the average, less than one propagule per generation.

Although all $F_{\text {ST }}$ values were large, they did differ from each other depending on the populations that were included in their calculations. As expected, the lowest apparent levels of gene flow were obtained when both Atlantic and Pacific populations were included. When populations from the two oceans were considered separately, $F_{\mathrm{ST}}$ values decreased in the Caribbean where only one morph is present but not in the eastern Pacific where the $\mathrm{C}^{\prime}$ and the $\mathrm{P}$ morphs coexist. Only when the two Pacific morphs were considered separately did $\mathrm{Nm}$ values increase by an order of magnitude to become similar to those obtained from the $\mathrm{C}$ morph. What is more, $F_{\mathrm{ST}}$ values in the eastern Pacific were very similar whether or not $E$. chamensis was included in the calculations. Thus, gene flow between the $\mathrm{P}$ and the $\mathrm{C}^{\prime}$ morphs was as low as gene flow between $E$. braziliensis and $E$. chamensis and between populations separated by the isthmus of Panama.

Average rates of immigration estimated from rare homozygotes, in excess of what might be expected from random mating between the residents, are also presented in Table 1. These values must be considered as rough estimates of overall immigration, because they are based on a few individuals, but their general consistency between populations and between years is encouraging. Despite the limitations of the 1986 data, they provided estimates of immigration that were compatible with estimates from the 1988 data. Our method of calculating immigration indicates that $0-2.5$ per cent of the individuals composing these populations may have been recent arrivals. This proportion may seem small until one considers that at an average density of 295 individuals per $\mathrm{m}^{2}$ (average of densities in 20 beaches studied by Dexter $(1974,1977,1979)$ and Jaramillo (1978)), a beach no wider than $100 \mathrm{~m}$ could contain in a 5 metre zone of the upper intertidal up to 3600 individuals that might have arrived within the last generation from another locality. This is a surprisingly large number of migrants for an organism with no planktonic larvae and, if true, it indicates that rafting or swimming by adults between beaches may not be an unusual phenomenon.

Does the presence of different genotypes at each beach result in genotype distributions different from those expected from the Hardy-Weinberg rule? Table 2 presents deviations of observed from expected heterozygosities and their significance, after correction for multiple testing. As can be seen, the generally low 
statistical power of testing for deviations from Hardy-Weinberg equilibrium (Lessios, 1992) resulted in non-significant deviations in every case except for two loci in Santelmo where the coexistence of two morphological populations is responsible for large numbers of homozygotes of more than one allele. However, although the frequencies of heterozygote excesses and deficiencies were approximately equal (35 vs. 39), the magnitudes of excesses were always slight (median $D_{\mathrm{H}}=0.025$ ) whereas those of deficiencies were large (median $D_{\mathrm{H}}=-0.717$ ), a difference that was highly significant (Mann-Whitney $U$-test on absolute values of $\left.D_{\mathrm{H}}, P=0.0000\right)$. An asymmetry in absolute magnitude of positive and negative deviations is expected when gene frequencies are different from 0.5 , even if the populations are panmictic (Majumder \& Chakraborty, 1981). However, the differences we observed are so extreme that they suggest that excesses may be caused by sampling error, whereas deficiencies may be the result of true rarity of heterozygotes. Note that of the 39 cases of heterozygote deficiency, 19 were due to a complete absence of observed heterozygotes from the sample. Although larger sample sizes are obviously needed, we can tentatively conclude that testing for Hardy-Weinberg equilibrium also provided circumstantial evidence that different genotypes in each beach produce fewer hybrids than might have been expected from random mating. Whatever the case might be at other beaches, this analysis confirms the existence of assortative mating (or lower hybrid survivorship) between the two morphotypes that coexist at Santelmo. All polymorphic loci at this locality showed a heterozygote deficit, which in two cases was significant.

\section{Discussion}

The theory behind the indirect assessment of gene flow from static gene frequencies is still being developed and relies on a number of assumptions that may not be met by natural populations (Boileau et al., 1992). Given the limitations of the theory and our data, we need to consider the degree to which our gene flow estimates are consistent with the assessed genetic divergence between populations of Excirolana braziliensis (Lessios \& Weinberg, in press). An exchange of one propagule per generation is considered sufficient to nullify the differentiating effects of genetic drift (Kimura \& Maruyama, 1971; Chakraborty \& Nei, 1974; Spieth, 1974; Slatkin \& Maruyama, 1975). Gene flow will also homogenize populations in the presence of diversifying selection, unless the selection coefficient is larger than the gene flow rate (Haldane, 1930; Li, 1976). Therefore, the fact that even populations belonging to the same morphotype of Excirolana braziliensis and separated by less than $1 \mathrm{~km}$ of coast line are

Table 2 Departures from heterozygosity $D_{\mathrm{H}}$ expected from Hardy-Weinberg equilibrium, calculated as $D_{\mathrm{H}}=($ observed heterozygote frequency - expected heterozygote frequency)/expected heterozygote frequency, in all polymorphic loci with codominant alleles

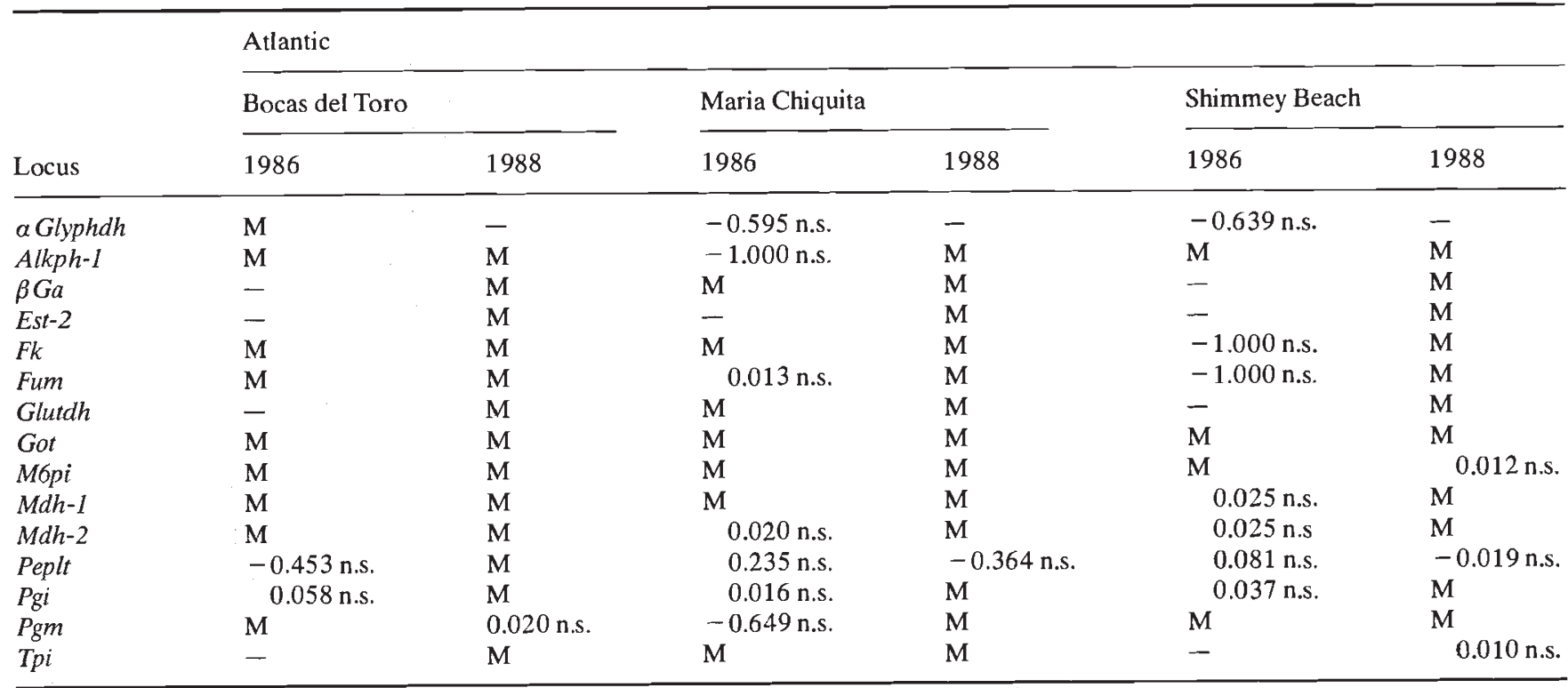

Significance of the departures is based on goodness of fit $\chi^{2}$ tests for overall heterozygosity (with homozygotes pooled in one class and heterozygotes pooled in another), employing a correction for continuity of 0.25 (Lessios, 1992). Significance values were adjusted with the sequential Bonferroni procedure (Rice, 1989) to take into consideration that 74 tests were performed.

n.s.: $P>0.05$; **: $0.005>P>0.001$.

M: monomorphic locus; --: no data. 


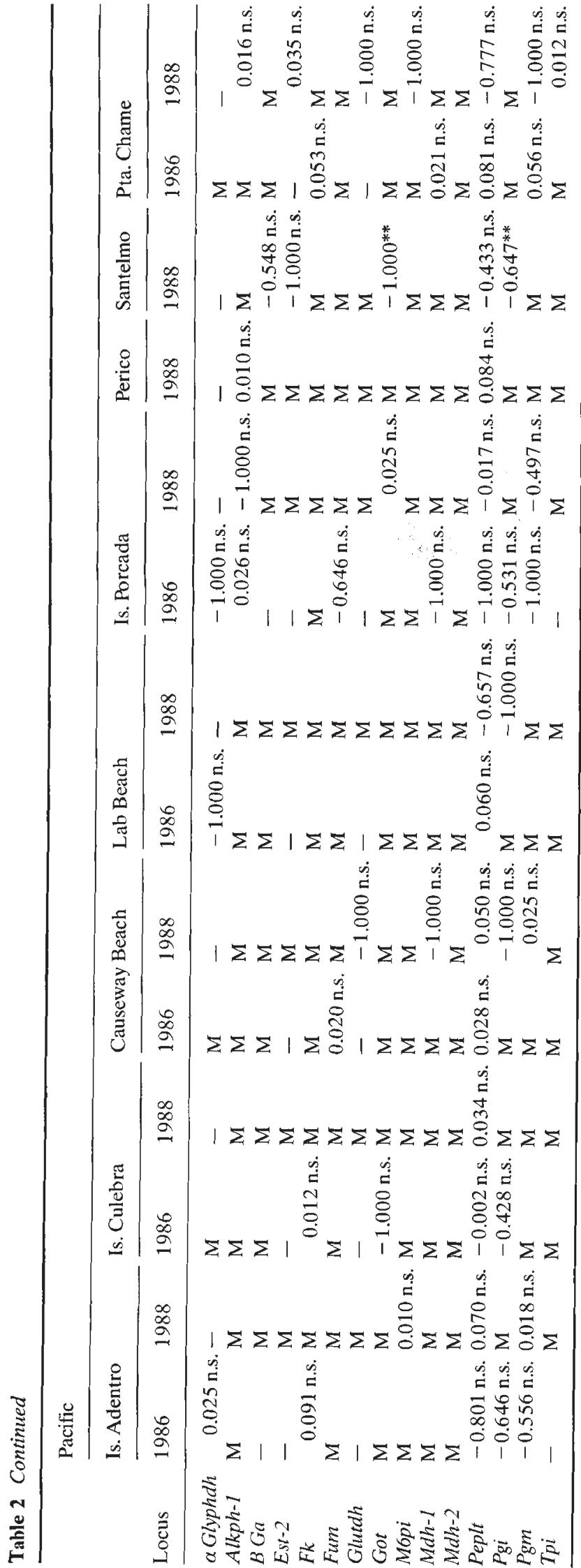

fixed (or nearly fixed) for alternate alleles in at least one locus (Lessios \& Weinberg, in press) must mean that rates of gene flow between these populations is very low. Thus, the high $\mathrm{Nm}^{*}$ values calculated by the private allele method from the 1986 data overestimate true gene flow, not only because they disagree with $N m_{\mathrm{F}_{\mathrm{ST}}}$ values from both years but also because they cannot be reconciled with the sharp genetic discontinuities obvious in our complete datum set. Gene flow estimates derived from $F_{\mathrm{ST}}$ statistics based on the 1988 data appear more reliable, judged by the criterion of observed genetic divergence between local populations; they indicate that less than one individual per generation transfers alleles between these populations. To what extent is this the result of low dispersal and to what extent does it come from reproductive isolation?

Comparisons of $N m_{F_{\mathrm{ST}}}$ values that include or exclude certain populations provide strong indications of reproductive isolation between the $\mathrm{P}$ and the $\mathrm{C}^{\prime}$ morphs in the eastern Pacific. Judged by the criterion of apparent gene flow across the central American isthmus, genetic exchange between the two eastern Pacific morphs must be almost non-existent. Populations of the same morph, on the other hand, are estimated to exchange genes at a rate which, although still small, is higher by one order of magnitude. The constriction of gene flow between morphs in the same ocean could have still been due to limited dispersal if populations belonging to the $\mathrm{P}$ and $\mathrm{C}^{\prime}$ morphs were segregated in different parts of the E. braziliensis range. However, the two morphs are geographically interspersed (Fig. 1) and even coexist on a single beach. Therefore, the restriction to gene flow between morphs relative to gene flow within morphs must resulted from mating choices of the animals themselves or from lower chances of hybrid survival. The existence of reproductive isolation between the two Pacific morphs is also indicated by significant heterozygote deficiencies at Santelmo. That apparent levels of gene flow in the eastern Pacific do not increase when both morphs are included but $E$. chamensis is excluded from the calculations suggests that the $\mathrm{P}$ and the $\mathrm{C}^{\prime}$ morphs are genetically as isolated from each other as they are from a recognized different species. Thus, consideration of patterns of gene flow confirm the conclusions of Lessios \& Weinberg (in press) based on genetic and morphological divergence and on phylogenetic relationships within Excirolana: the $\mathrm{P}$ and $\mathrm{C}^{\prime}$ morphs are reproductively isolated and belong to different species.

If the $\mathrm{P}$ and $\mathrm{C}^{\prime}$ morphs have speciated and if they are both barred by the isthmus from exchanging genes with the $\mathrm{C}$ morph, then the only comparisons that can provide an indication of current patterns of gene flow in Excirolana are the ones between populations that 
belong to the same morph. $N m_{\mathrm{Fst}}$ values calculated for each of the three morphs separately may be larger than the ones that include all morphs, but they are still smaller than unity. They are also much lower than those determined by Waples (1987) for populations of ten species of eastern Pacific fish, including one of a viviparous species with sedentary adults. $F_{\mathrm{ST}}$ values in Excirolana are larger than those of populations of the land snail Triodopsis albolabris that have been isolated for a minimum of 100 years (McCracken \& Brussard, 1980). Among six species of troglobitic arthropods for which Caccone (1985) estimated rates of gene flow by the private allele method, only two show lower values of $\mathrm{Nm}$ than populations of the same morph of Excirolana. In fact, $F_{\mathrm{ST}}$ values and gene flow rate estimates between populations of the same morph of Excirolana fall close to the middle of the range of similar estimates for populations of plenthodontid salamanders separated by much larger geographical distances (Larson et al., 1984). These salamanders exemplify a group of organisms in which gene flow rates are very low (Slatkin, 1981, 1985b). Given the lack of a planktonic larva and the difficulties adults probably face in moving from beach to beach, it would be easy to conclude that low gene flow in E. braziliensis is entirely the result of low dispersal; however, our estimates of immigration suggest that individuals may move between populations more freely than alleles.

The method we have used for estimating immigration on the basis of rare homozygotes calculates the proportion of individuals at a beach that are possible migrants from elsewhere $\left(m_{\mathrm{im}}\right)$ whereas methods of gene flow estimation produce approximations of the number of propagules per generation that transfer genes between the sampled populations $(\mathrm{Nm})$. For this reason, it is not possible to compare migration and gene flow directly. However if, as we estimate, there can be thousands of immigrants between beaches in every generation, indiscriminate mating with residents should have resulted in adjacent populations that are genetically similar. That we have found fixed differences between populations of the same morph inhabiting neighbouring coves could be explained by one of two postulates: either our calculations of migration are wrong or immigrants fail to leave behind as many offspring as would have been expected from random mating.

Our method of calculating migration can be criticized on various counts. On theoretical grounds, our use of gene frequencies from the same generation to calculate both number of rare homozygotes expected from random mating within a population and immigration rates from other populations assumes that the number of propagules from each source stays constant through time, an assumption that remains to be tested. On practical grounds, two snapshots in time of a stochastic event of low probability are not adequate for the determination of its rate. An additional difficulty for the Pacific samples is that we did not measure the isopods we used for electrophoresis, so we do not know whether suspected migrants into a given beach are of the same morphotype as the residents. Finally, we have to examine the possibility that our basic assumption is wrong and that the excess homozygotes of rare alleles, which we have considered to be migrants, are in fact representative of a small selfsustaining population that has been present on that beach for long periods of time. How would each of these difficulties undermine the conclusion that immigrants do not cross at random with residents?

Our subtracting numbers of homozygotes expected from Hardy-Weinberg equilibrium from the number of potential migrants only serves to decrease apparent immigration rates. That we have estimates of immigration from only two generations undoubtedly decreases their validity; however, our two samples of each locality in different years suggest that, at least in the Pacific, the presence of homozygotes of rare alleles is not the result of an unusual dispersal event but a constant feature that can be observed multiple times. That we do not know the morphotype to which Pacific rare genotypes belong is a serious shortcoming. However, although our morphological analysis (Lessios et al., in press) of populations at the same 11 beaches involved sample sizes only slightly smaller than the electrophoretic survey, it discovered only two morphological outliers: one individual of the $\mathrm{P}$ morph in Isla Culebra and one individual of the $\mathrm{C}^{\prime}$ morph in Perico. This is a much smaller proportion of migrants than is indicated by the genetic analysis and signifies that many of the individuals with distinct genotypes probably had the same morphotype as the residents. What is more, Table 1 indicates apparent migrants in the 1986 samples of the Caribbean localities where only one morph is known to exist. It is, therefore, difficult to conclude that reproductive isolation between the two Pacific morphs can be solely responsible for migration that does not result in gene flow. Finally, if a secondary, low-level genetic population is always present at each beach, its lack of assimilation by the predominant population indicates even more strongly that different genotypes have a lower probability of leaving behind viable hybrid offspring.

If our estimates of migration between beaches are roughly correct, why do populations remain genetically distinct? One possibility is that migrants do mate at random with the residents but strong selection quickly eliminates the 'wrong' alleles at each beach. Although 
this explanation is consistent with the low degree of genetic and morphological within-population polymorphism, it otherwise seems unlikely. It is hard to imagine selective pressures that differ so much between beaches $1 \mathrm{~km}$ apart that they lead to near-fixation of an allele in one population and almost complete elimination in another. What is more, if selection were responsible for determining the genotype that survives at each beach, then its pressures would also change direction over short periods of time because in Isla Porcada we have documented the replacement of one genotype by another over a 2-year period (Lessios et $a l$., in press). There is also no reason to suppose that all migrants are post-reproductive individuals that have already left their offspring in the locality from which they came or that all reproduction in this clearly dioecious species with a well-defined copulatory system (Klapow, 1970; Dexter, 1977) is asexual. A more credible possibility is that even genotypes of the same morph (whether arriving at each generation or existing for a long time at each beach) do not exchange genes at random. Our data on apparent gene flow within morphs suggest that the degree of this reproductive isolation is not as strong as that existing between morphs. It would, therefore, be wrong to conclude that there are as many species of Excirolana as there are beaches inhabited by different genotypes. However, it seems probable that low gene flow in Excirolana is not only due to low patterns of present-day dispersal but also to difficulties faced by the migrants in injecting their genes into resident populations. This reproductive isolation must have evolved because of past restrictions to migration, more severe than we see today, or because of rapid divergence between populations. It could reasonably be considered the result of infrequent local extinctions and recolonizations of beaches by a few individuals from a single source and rapid divergence from the parental population due to founder effects (Lessios et al., in press; Lessios \& Weinberg, in press).

\section{Acknowledgements}

A. Calderon, U. Schober and A. Velarde helped with the collections, A. and L. Calderon, F. de Carlo, A. Graybeal and M. Soriano helped in the laboratory and E. Bermingham, J. B. C. Jackson, Y. Karakousis, N. Knowlton, M. Lazaridou-Dimitriadou, E. Mayr, D. R. Robertson, V. Starczak and J. Weterer provided comments on previous versions of the manuscript. We thank D. Smith for translations of German articles and $R$. Brusca for examining specimens and discussion of this work. This research was supported by the Molecular Evolution, the Scholarly Studies, the Short Term Visitor and the Fellowship Programs of the Smith- sonian Institution, the National Geographic Society and the Woods Hole Oceanographic Institution.

\section{References}

BAKER, A. J., DENNISON, M. D., LYNCH, A. AND LEGRAND, G. 1990. Genetic divergence in peripherally isolated populations of chaffinches in the Atlantic islands. Evolution, 44, 981-999.

BAKER, A. J. AND MOEED, A. 1987. Rapid genetic differentiation and founder effect in colonizing populations of common mynas (Acridotheres tristis). Evolution, 41, 525-538.

BARTON, N. H. 1988. Speciation. In: Myers, A. A. and Giller, P. S. (eds), Analytical Biogeography, Chapman and Hall, London, pp. 185-218.

BOILEAU, M. G., HEBERT, P. D. N. AND SCHWARTZ, S. S. 1992. Nonequilibrium gene frequency divergence: persistent founder effects in natural populations. J. Evol. Biol., 5, 25-39.

вотт, R. 1954. Ein neuer litoraler Isopod aus Peru. Senckenb. Biol., 35, 107-108.

BRUSCA, R. C. 1980. Common Intertidal Invertebrates of the Gulf of California, 2nd edn, University of Arizona Press, Tucson.

BRUSCA, R. C. AND IVERSON, E. W. 1985. A guide to the marine isopod Crustacea of Pacific Costa Rica. Rev. Biol. Trop., 33, 1-77.

BRUSCA, R. C. AND WEINBERG, J. R. 1987. A new isopod crustacean from Pacific Panama, Excirolana chamensis new species (Isopoda: Flabellifera: Cirolanidae). Contributions in Science, LA County Mus., 392, 11-17.

CACCONE, A. 1985. Gene flow in cave arthropods: a qualitative and quantitative approach. Evolution, 39, 1223-1235.

CACCONE, A. AND SBORDONI, v. 1987. Molecular evolutionary divergence among North American cave crickets. I. Allozyme variation. Evolution, 41, 1198-1214.

CHAKRABORTY, R. AND NEI, M. 1974. Dynamics of gene differentiation between incompletely isolated populations of unequal sizes. Theor. Pop. Biol., 5, 460-469.

COATES, A. G., JACKSON, J. B. C., COLLINS, L. S., CRONIN, T. M., DOWSET, H. J., BYBELL, L. M., JUNG, P. AND OBANDO, J. A. 1992. Closure of the Isthmus of Panama: the near-shore marine record of Costa Rica and western Panama. Bull. Geol. Soc. Am., 104, 814-828.

Crouau-ROY, B. 1989. Population studies on an endemic troglobitic beetle: geographical patterns of genetic variation, gene flow and genetic structure compared with morphometric data. Genetics, 121, 571-582.

DEXTER, D. M. 1974. The sandy beach fauna of the Pacific and Atlantic coasts of Costa Rica and Colombia. Rev. Biol. Trop., 22, 51-66.

DEXTER, D. M. 1977. Natural history of the Pan-American sand beach isopod Excirolana braziliensis (Crustacea: Malacostraca). J. Zool. Lond., 183, 103-109.

DEXTER, D. M. 1979. Community structure and seasonal variation in intertidal Panamanian sandy beaches. Est. Coast. Mar. Sci., 9, 543-558.

EMIGH, T. H. 1980. A comparison of tests for Hardy-Weinberg equilibrium. Biometrics., 36, 627-642.

ENDLER, J. A. 1977. Geographic Variation, Speciation and Clines. Princeton University Press, Princeton, New Jersey. 
EWENS, W. J., BROCKWELL, P. J., GANI, J. M. AND RESNICK, S. I. 1987. Minimum viable population size in the presence of catastrophes. In: Soule, M. E. (ed.) Viable Populations for Conservation, Cambridge University Press, Cambridge, pp. 59-68.

GLYNN, P. W., DEXTER, D. M. AND BOWMAN, T. E. 1975. Excirolana braziliensis a Pan-American sand beach isopod: taxonomic status, zonation and distribution. J. Zool. Lond., 175, 509-521.

HALDANE, J. B. S. 1930. A mathematical theory of natural and artificial selection. VI. Isolation. Proc. Cambridge Philos. Soc., 26, 220-230.

JARAMILLO, E. 1978. Zonacion y estructura de la comunidad macrofaunistica en playas de arena del Sur de Chile (Mehuin, Valdivia). Stud. Neotrop. Fauna Environ., 17, 71-92.

JOHNSON, M. S., CLARKE, B. AND MURRAY, J. 1988. Discrepancies in the estimation of gene flow in Partula. Genetics, 120, 233-238.

KEIGWIN, L. D. 1978. Pliocene closing of the Isthmus of Panama, based on biostratigraphic evidence from nearby Pacific Ocean and Caribbean Sea cores. Geology, 6, 630-634.

KEIGWIN, L. D. 1982. Isotopic paleoceanography of the Caribbean and east Pacific: Role of Panama uplift in Late Neogene time. Science, 217, 350-353.

KIMURA, M. AND MARUYAMA, T. 1971. Pattern of neutral polymorphism in a geographically structured population. Genet. Res. Camb., 18, 125-131.

KLAPOW, L. A. 1970. Ovoviviparity in the genus Excirolana (Crustacea: Isopoda). J. Zool. Lond., 362, 359-369.

LARSON, A., WAKE, D. B. AND YANEV, K. P. 1984. Measuring gene flow among populations having high levels of genetic fragmentation. Genetics, 106, 293-308.

LESS1OS, H. A. 1992. Testing electrophoretic data for agreement with Hardy-Weinberg expectations. Mar. Biol., 112, 517-523.

LESSIOS, H. L. AND WEINBERG, J. R. Genetic and morphological divergence among morphotypes of the isopod Excirolana on the two sides of the Isthmus of Panama. Evolution, in press.

LESSIOS, H. L., WEINBERG, J. R. AND STARCZAK, v. R. Temporal variation in populations of the marine isopod Excirolana: How stable are gene frequencies and morphology? Evolution, in press.

LEVENE, H. 1949. On a matching problem arising in genetics. Ann. Math. Stat., 20, 91-94.

LI, W. H. 1976. Effect of migration on genetic distance. Am. Nat., 110, 841-847.

McCAULEY, D. E. 1991. Genetic consequences of local population extinction and recolonization. Trend. Ecol. Evol., 6, $5-8$.

McCRACKEN, G. F. AND BRUSSARD, P. F. 1980. The population biology of the white-lipped land snail, Triodopsis albolabris: genetic variability. Evolution, 34, 92-104.

MAJUMDER, P. P. AND CHAKRABORTY, R. 1981. Mean and variance of the number of samples showing heterozygote excess or deficiency. Heredity, 47, 259-262.

MARUYAMA, T. AND KIMURA, M. 1980. Genetic variability and effective population size when local extinction and recolonization of subpopulations are frequent. Proc. Natl. Acad. Sci. USA, 77, 6710-6714.

NEI, M., ChaKRaVARTI, A. AND TATENo, y. 1977. Mean and variance of Fst in a finite number of incompletely isolated populations. Theor. Pop. Biol., 11, 291-306.

PAMILO, P. AND VARVIO-AHO, s. 1984. Testing genotype frequencies and heterozygosities. Mar. Biol., 79, 99-100.

RICE, w. R. 1989. Analysing tables of statistical tests. Evolution, 43, 223-225.

SAITo, T. 1976. Geologic significance of coiling direction in the planktonic foraminifera Pulleniatina. Geology, 4, 305-312.

SCHUSTER, O. 1954. Zwei neue Crustaceen von der pazifischen Küste Mittel-Americas (Amphipoda und Isopoda), Senckenb. Biol., 35, 103-105.

SELANDER, R. K. 1975. Stochastic factors in the genetic structure of populations. In: Estabrook, G. F. (ed.) Proceedings of the Eighth International Conference on Numerical Taxonomy, Freeman, San Francisco, pp. 284-331.

SLATKIN, M. 1977. Gene flow and genetic drift in a species subject to frequent local extinction. Theor. Pop. Biol., 12, 253-262.

SLATK1N, M. 1981. Estimating levels of gene flow in natural populations. Genetics, 99, 323-335.

Slatkin, M. 1985a. Gene flow in natural populations. Ann. Rev. Ecol. Syst., 16, 393-430.

SLATKIN, M. 1985b. Rare alleles as indicators of gene flow. Evolution, 39, 53-65.

SLATKIN, M. AND BARTON, N. H. 1989. A comparison of three indirect methods for estimating average levels of gene flow. Evolution, 43, 1349-1368.

SlatKin, M. AND MARUYAMA, T. 1975. The influence of gene flow on genetic distance. Am. Nat., 109, 597-601.

SPIETH, P. T. 1974. Gene flow and genetic differentiation. Genetics, 78, 961-965.

SWOFFORD, D. L. AND SElANDER, R. B. 1989. BIOSYs-1. A Computer Program for the Analysis of Allelic Variation in Population Genetics and Biochemical Systematics. Illinois Natural History Survey, Champaign, Illinois.

WADE, M. J. AND McCAULEY, D. E. 1988. Extinction and recolonization: their effects on the genetic differentiation of local populations. Evolution, 42, 995-1005.

WAPLES, R. S. 1987. A multispecies approach to the analysis of gene flow in marine shore fishes. Evolution, 41, 385-400.

WEINBERG, J. R. AND STARCZAK, v. R. 1988. Morphological differences and low dispersal between local populations of the tropical beach isopod, Excirolana braziliensis. Bull. Mar. Sci., 442, 296-309.

WEINBERG, J. R. AND STARCZAK, V. R. 1989. Morphological divergence of eastern Pacific and Caribbean isopods: effects of a land barrier and the Panama Canal. Mar. Biol., 103, 143-152.

WhitLOCK, M. C. AND McCAULEY, D. E. 1990. Some population genetic consequences of colony formation and extinction: genetic correlations within founding groups. Evolution, 44, 1717-1724.

WRIGHT, s. 1940. Breeding structure of populations in relation to speciation. Am. Nat., 74, 232-248.

WRIGHT, s. 1965. The interpretation of population structure by F-statistics with special regard to systems of mating. Evolution, 19, 395-420. 


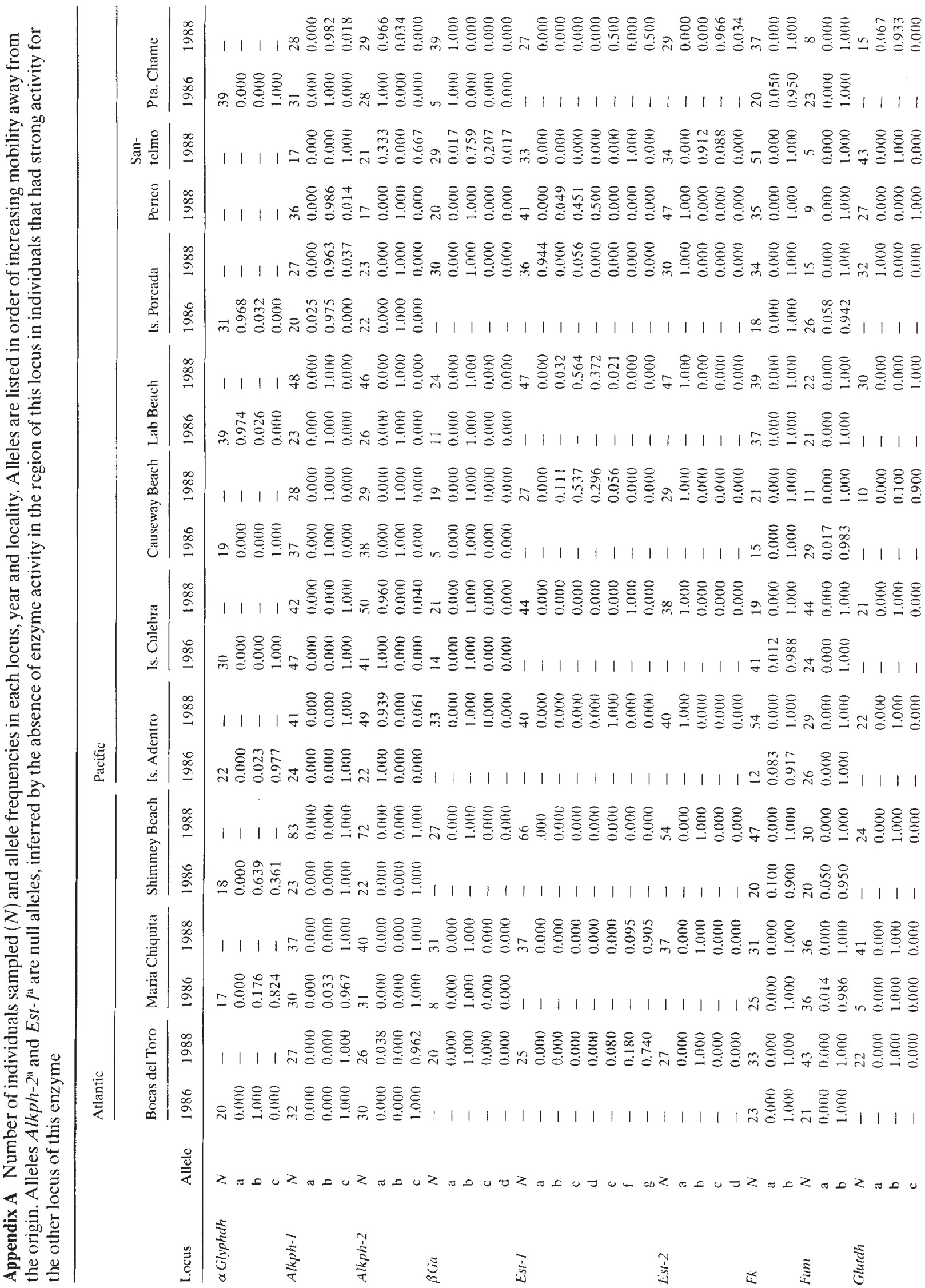




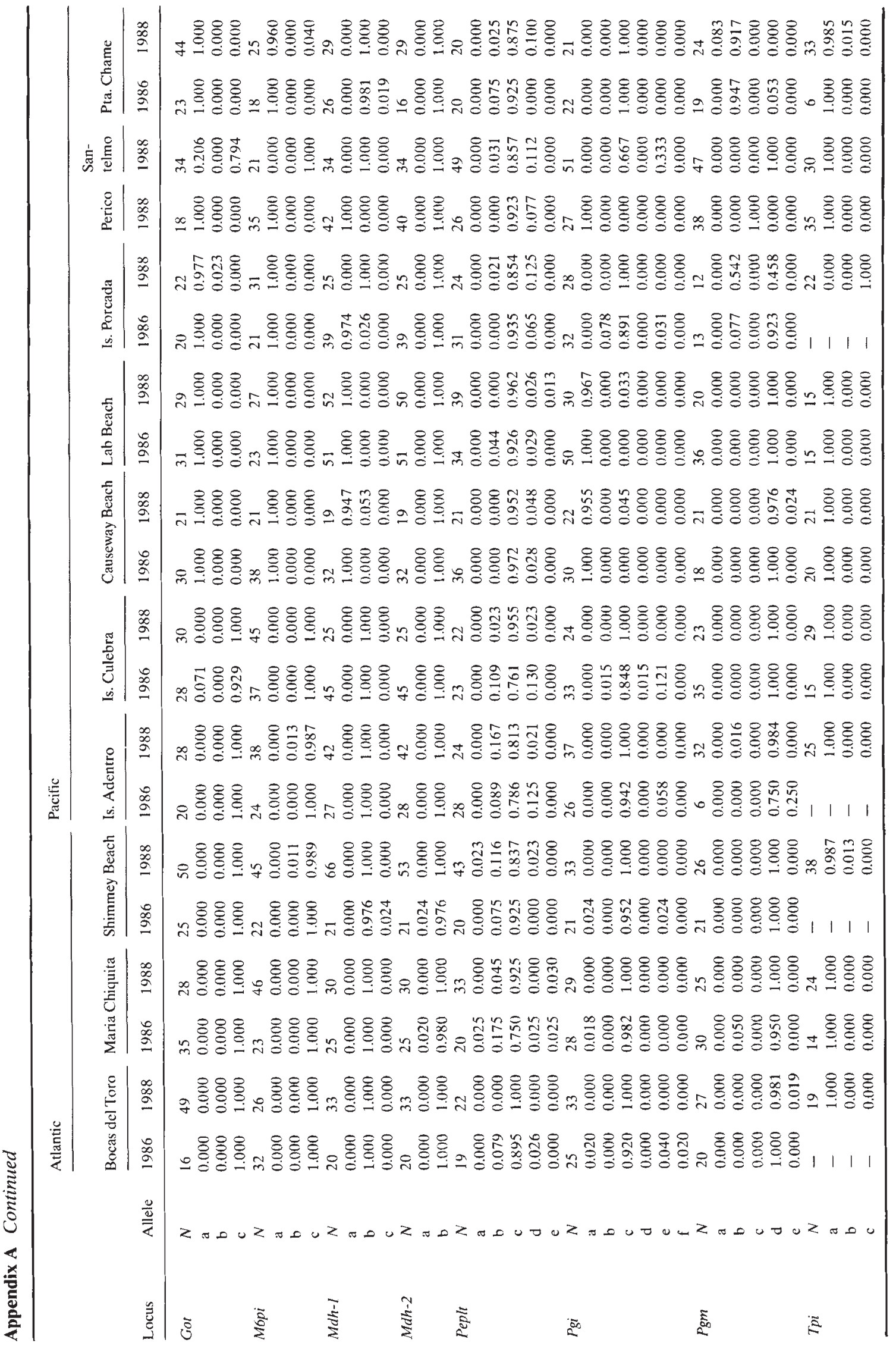

